\title{
HUBUNGAN PENGETAHUAN BIDAN TENTANG INFEKSI NOSOKOMIAL DENGAN TINDAKAN PENCEGAHANNYA PADA PASIEN BEDAH SEKSIO SESAREA
}

\author{
Paskah Rina Situmorang \\ Program Studi Profesi Ners Universitas Imelda Medan \\ Email: paskahsitumorang85@gmail.com
}

\begin{abstract}
Nosocomial infection is an infection obtained by patients who are undergoing treatment in a hospital. Nosocomial infections stem from non-invasive measures. Prantara that cause nosocomial infections are microorganisms, medications and the environment. Where, is a factor causing nosocomial infection that is the focus of this study is midwives who are less aware of personal' hygiene. This study aims to determine the relationship of knowledge of midwives about nosocomial infections with prevention measures in cesarean section surgical patients at Imelda General Hospital Medan. This research is a quantitative study with a correlational research design with Cross Sectional approach, where sampling is done with a total sampling technique with a total of 31 midwives, and data collection is done using a questionnaire. The results of the study of midwife knowledge about nosocomial infections are mostly knowledgeable, 21 people (67.8\%), while the majority of prevention measures are good, 19 people (61.3\%). The results of the study were tested using the Spearman Rank test to see the relationship between knowledge of midwives about nosocomial infections and their preventive measures in post-cesarean section patients, the results obtained with a probability value $(p)=0.011(p<0.05)$, which means there is a relationship where $(r)=0.452$, it means that the strength of the relationship is sufficient and this relationship is positive which means that if the midwife's knowledge of nosocomial infection is sufficient, the more sufficient value of infection prevention measures is obtained.
\end{abstract}

Keywords: knowledge, nosocomial infection, preventive measures

\section{PENDAHULUAN}

Infeksi nosokomial merupakan infeksi yang terjadi di rumah sakit yang mana menyerang pasien dalam proses perawatan. Rumah sakit merupakan tempat dimana pasien mecari kesembuhan terkait keluahan yang dialaminya, dan tempat penyebaran infeksi dikarenakan populasi dari mikroorganisme yang sangat tinggi. Mikroorganisme ini hidup dan berkembangbiak di lingkungan rumah sakit seperti lantai rumah sakit, air, udara, alat-ala medis dan non medis (Tombokan, Waworuntu, \& Buntuan, 2016).

Angka kejadian infeksi nosokomial di rumah sakit di seluruh dunia mencapai $9 \%$ atau kurang lebih 1,40 juta pasien yang dirawat inap terkena infeksi nosokomial. Hasil penelitian yang dilakukan oleh WHO mengenai infeksi nosokomial diperoleh sekitar 8,70\% dari 55 rumah sakit di 14 negara di Eropa, Timut Tengah, Asia Tenggara dan Pasifik. Prevalensi infeksi 
nosokomial banyak ditemui di Mediterania Timur dan Asia Tenggara sebesar $11,80 \%$ dan 10 . Sedangkan di bagian Eropa dan Pasifik Barat masingmasing sebesar $7,70 \%$ dan $9 \%$ (Tombokan et al., 2016). Penelitian serupa juga dilakukan di 11 rumah sakit di daerah DKI Jakarta tahun 2004 menunjukkan bahwa 9,80\% pasien yang dirawat inap di rumah sakit mengalami infeksi nosokomial. Infeksi nosokomial yang sering terjadi pada infeksi daerah operasi, infeksi saluran kemih, infeksi saluran pernafasan bagian bawah. (Achmad, 2017).

Kejadian infeksi nosokomial termasuk indikator mutu dari sebuah rumah sakit. Kejadian infeksi nosokomial di sebuah rumah sakit dapat dikatakan bahwa status kesehatan pasien semakin buruk. Kejadian infeksi nosokomial di RSU Haji Surabaya dipengaruhi oleh beberapa faktor dimana faktor-faktor tersebut saling berpengaruh positif dan berpengaruh pada status kesehatan (Fitriany, Farouk, \& Taqwa, 2016).

Faktor pelayanan kesehatan dapat diartikan bahwa terjangkaunya pelayanaan kesehatan dan bagaimana kualitas pelayanan kesehatan yang diberikan kepada pasien. Faktor lingkungan berhubungan dengan petugas kesehatan dan pasien dimana petugas kesehatan pemberi pelayanan kesehatan,
Perawat atau tenaga kesehatan lainnya lebih sering berinteraksi dengan pasien sehingga tenaga kesehatan memiliki peran yang sangat penting bagi pasien, termasuk pengetahuan dari tenaga kesehatan dalam mengidentifikasi tentang infeksi nosokomial, sehingga infeksi nosokomial akan dapat ditangani dengan cepat, sehingga mengurangi angka kejadian infeksi nosokomial di rumah sakit. Rumah sakit harus melakukan tindakan agar dapat mengendalikan angka kejadian infeksi nosokomial sehingga tidak semakin meningkat. Salah satu langka strategi mengendalikan infeksi nosokomial dengan melakukan surveilans (Achmad, 2017).

Meningkatnya angka prevalensi kejadian infeksi nosokomial merupakan ancaman bagi pelayanan kesehatan di rumah sakit. PPI atau yang dikenal dengan Pencegahan dan Pengendalian infeksi di palayanan kesehatan merupakan standar mutu dari pelayanan yang penting bagi pasien, petugas kesehatan dan pengunjung. Pengendalian infeksi harus dilakukan oleh seluruh tenaga kesehatan yang ada di rumah sakit untuk melindungi pasien, petugas kesehatan dan pengunjung dari kejadinan infeksi nosokomial dengan memperhatikan cost effectiveness (Kemenkumham, 2015). 
Peran perawat dalam pencegahan infeksi sangat penting dimana rata-rata setiap harinya perawat terpapar dengan pasien sekitar 7-8 jam per hari dan efektif kontak langsung kepada pasien adalah setengah jam kerja yaitu sekitar 4 jam, sehingga akan menjadi sumber utama terpaparnya infeksi nosokomial. Fenomena yang terjadi di rumah sakit Imelda pekerja Indonesia menunjukan bahwa pencegahan dan pengendalian infeksi belum dilakukan secara optimal dan hasil wawancara yang dilakukan peneliti kepada 5 responden mengatakan kurang memahami tentang infeksi nosokomial dan cara pencegahannya pada pasien pasca bedah. Oleh karena itu peneliti tertarik untuk melakukan penelitian mengenai hubungan pengetahuan bidan tentang infeksi nosokomial dengan tindakan pencegahannya pada pasien pasca bedah seksio sesarea di Rumah Sakit Umum Imelda Pekerja Indonesia Medan.

\section{METODE}

Jenis penelitian adalah penelitian kuantitatif dengan desain penelitian korelasional dan pendekatan Cross Sectional. Penelitian bertujuan untuk mengetahui sejauh mana hubungan pengetahuan bidan tentang infeksi nosokomial dengan tindakan pencegahan pada pasien pasca bedah seksio sesarea di Rumah Sakit Umum
Imelda Pekerja Indonesia Medan pada bulan Maret - Juli 2019. Populasi dalam penelitian ini adalah bidan yang ada di ruang rawat inap ruang Melati, Kemuning, Dalima yaitu sebanyak 31 orang bidan. Tehnik pengambilan sampel adalah total sampling.

Aspek pengukuran dengan menggunakan kuesioner. Kuesioner pengukuran pengetahuan bidan menggunakan multiple choice dan pengukuran tindakan pencegahan infeksi menggunakan dicotomi dengan jumlah. Metode analisis data yang digunakan adalah analisis Univariat dan Bivariat. Dimana analisis Univariat untuk mengetahui distribusi frekuensi, dan persentase dari masing-masing variabel bebas dan variabel terikat. Analisis Bivariat untuk mengetahui hubungan antara variabel bebas dan terikat dengan menggunakan uji statistik Rank Spearman (Aziz, 2017).

\section{HASIL DAN PEMBAHASAN}

\section{Analisis Univariat}

Karkteristik responden berdasarkan umur mayoritas kelompok umur bidan 25-30 tahun yaitu sebanyak 23 orang $(74,2 \%)$. Berdasarkan tingkat pendidikan bidan mayoritas DIII kebidanan yaitu 29 orang $(93,5 \%)$, dan S-1 Kesehatan Masyarakat sebanyak 2 orang $(6,5 \%)$. 
Berdasarkan lama bekerja bidan mayoritas adalah dalam rentang waktu 5-10 tahun sebanyak 18 orang (58\%). Berdasarkan pengetahuan bidan tentang pengertian infeksi nosokomial mayoritas pengetahuan bidan tentang pengertian infeksi nosokomial yaitu rendah sebanyak 15 orang $(48,4 \%)$. Berdasarkan pengetahuan bidan tentang jenis-jenis infeksi nosokomial yaitu sedang sebanyak 18 orang $(58,1 \%)$. Berdasarkan pengetahuan bidan tentang faktor-faktor terjadinya infeksi nosokomial yaitu sedang sebanyak 23 orang $(74,2 \%)$.

Berdasarkan pengetahuan bidan tentang pertahanan terhadap infeksi nosokomial yaitu baik sebanyak 22 orang $(71 \%)$. Berdasarkan pengetahuan bidan tentang gejala infeksi nosokomial diketahui bahwa mayoritas pengetahuan bidan tentang gejala infeksi nosokomial yaitu sedang sebanyak 19 orang $(61,3 \%)$. Berdasarkan pengetahuan bidan tentang infeksi nosokomial diketahui bahwa mayoritas pengetahuan bidan tentang infeksi nosokomial yaitu sedang sebanyak 20 orang $(64,5 \%)$. Berdasarkan tindakan pencegahan infeksi nosokomial yang dilakukan bidan diketahui bahwa mayoritas tindakan pencegahan infeksi nosokomial yaitu baik sebanyak 19 orang $(61,3 \%)$.
Analisis Bivariat

Berdasarkan tabulasi silang pengetahuan bidan tentang infeksi nosokomial dengan tindakan pencegahannya dapat dilihat bahwa pengetahuan bidan tentang infeksi nosokomial sedang yaitu 20 orang $(64,5 \%)$ dengan tindakan pencegahan infeksi nosokomial baik dan sedang masing-masing 9 orang $(29,0 \%)$. Pengetahuan bidan tentang infeksi nosokomial baik yaitu 11 orang $(35,5 \%)$ dengan tindakan pencegahan infeksi nosokomial baik 10 orang (32,3\%).

Berdasarkan tabulasi silang pengetahuan bidan tentang infeksi nosokomial dengan tindakan pencegahannya dengan menggunakan uji statistik dengan menggunakan uji Rank Spearman diperoleh hasil sebagai berikut hubungan pengetahuan bidan tentang infeksi nosokomial dengan tindakan pencegahan infeksi nosokomial dengan nilai probabilitas $(\mathrm{p})=0,011$ $(\mathrm{p}<0,05)$ berarti ada hubungan pengetahuan bidan tentang infeksi nosokomial dengan tindakan pencegahan infeksi nosokomial. Kekuatan hubungan $(r)=0,452$, berarti kekuatan hubungannya cukup.

\section{Pembahasan}

Pelayanan rumah sakit yang bermutu dapat dinilai melalui berbagai indikator, salah satunya dengan melakukan pencegahan dan pengendalian infeksi. 
Kejadian infeksi nosokomial menyebabkan mutu pelayanan yang tidak optimal, sehingga diperlukan tindakan yang tepat dalam mencegah ataupun mengurangi angka kejadian infeksi nosokomial (Zulkarnain, 2018).

Hasil penelitian yang diperoleh berdasarkan usia dari bidan berusia 25 30 tahun sebanyak 23 orang $(74,2 \%)$. Usia dapat mempengaruhi daya tangkap dan pola pikir dari seseorang. Semakin bertambahnya usia maka semakin berkembangnya daya tangkap dan pola pikir dari individu tersebut, sehingga pengetahuan yang diperoleh semakin baik (Fitriana, Pratiwi, \& Sutanto, 2015).

Berdasarkan tingkat pendidikan ratarata bidan berpendidikan D-III Kebidanan yaitu sebesar 29 orang (93,5 $\%)$. Pengetahuan sangat erat kaitannya dengan pendidikan dimana diharapkan seseorang dengan pendidikan tinggi, maka orang tersebut akan semakin luas pula pengetahuannya (Notoatmodjo, 2012). Pendidikan dapat menjadikan seseorang dapat lebih mudah memahami, mempelajari, mengubah dan membentuk cara pandang dan pola pikir seseorang.

Berdasarkan lama kerja rata-rata bidan yang bekerja di rumah sakit Imelda bekerja diatas 5-10 tahun sebanyak 18 orang (58\%). Dimana perawat yang bekerja diatas 5-10 tahun memiliki pengalaman yang banyak saat bekerja, sehingga dalam proses mengembangkan diri dan memberikan pelayanan kepada pasien lebih baik.

Hasil penelitian yang dilakukan dengan menggunakan uji Rank Spearman untuk melihat hubungan pengetahuan bidan tentang infeksi nosokomial dengan tindakan pencegahan infeksi nosokomial maka diperoleh hasil dengan nilai probabilitas $(\mathrm{p})=0,011(\mathrm{p}<0,05)$ yang artinya ada hubungan dengan kekuatan hubungan (r) $=0,452$, berarti kekuatan hubungannya cukup dan hubungan ini bersifat positif yang artinya jika pengetahuan perawat tentang infeksi nosokomial cukup maka makin cukup nilai tindakan pencegahan infeksi yang dilakukan.

Hal ini dibuktikan oleh Notoatmodjo (2012), yang menyatakan pengetahuan atau kognitif merupakan domain yang sangat penting dalam membentuk tindakan seseorang (overt behavior). Hasil penelitian Puspasari (2015) menyatakan tingkat pengetahuan responden baik, sikap responden baik, dan pencegahan infeksi nosokomial responden baik. Penelitian ini mendapatkan ada hubungan positif pengetahuan dan sikap perawat dengan pencegahan infeksi nosokomial di ruang Rawat Inap Rumah Sakit Paru dr. Ario Wirawan Salatiga Jawa Tengah. Penelitian Sulistyowati 
mendapatkan ada hubungan antara pengetahuan perawat tentang infeksi nosokomial dengan perilaku pencegahan infeksi nosocomial, tetapi tidak ada hubungan antara sikap perawat tentang infeksi nosokomial dengan perilaku pencegahan infeksi nosokomial.

Penelitian Zulkarnain

menyatakan ada huhungan antara perilaku (pengetahuan, sikap, keterampilan) perawat terhadap tindakan pencegahan infeksi nosokomial (phelibitis) di ruang perawatan interna RSUD Bima. Penelitian Suharto dan Suminar, (2017) menyatakan adanya hubungan pengetahuan dan sikap perawat dengan tindakan pencegahan infeksi di ruang ICU.

Beberapa prinsip dasar yang penting dalam kriteria infeksi nosokomial adalah informasi yang digunakan untuk menentukan adanya infeksi yang diklassifikasi berdasar kombinasi antara hasil pemeriksaan klinis dan hasil pemeriksaan laboratorium atau tes-tes lainnya. Bukti klinis adanya infeksi didapat dari observasi langsung pada lokasi infeksi pada pasien atau dari sumber-sumber data yang lain, misalnya dari status pasien. Bukti laboratorium adalah hasil biakan, tes deteksi antigen atau antibodi, atau visualisasi mikroskopis (Ibrahim, 2019).

Salah satu strategi untuk melindungi dan mengurangi infeksi di rumah sakit adalah melakukan tindakan kewaspadaan standar atau Standard Precaution. Hand hygiene merupakan teknik dasar yang paling penting dalam pencegahan dan pengontrolan penularan infeksi yang termasuk salah satu komponen dalam kewaspadaan standar (Monica P, 2016). Dengan mengenali tanda dan gejala awal infeksi, perawat dapat lebih waspada dalam memberikan perawatan terhadap kebutuhan pasien, terapi dan tindakan keperawatan yang mendukung.

\section{KESIMPULAN DAN SARAN}

\section{Kesimpulan}

1. Karakteristik responden berdasarkan pengetahuan bidan tentang pengertian infeksi nosokomial mayoritas kategori rendah

2. Karakteristik responden berdasarkan pengetahuan bidan tentang jenisjenis infeksi nosokomial mayoritas kategori sedang

3. Karakteristik responden berdasarkan pengetahuan bidan tentang faktorfaktor terjadinya infeksi nosokomial mayoritas kategori sedang

4. Karakteristik responden berdasarkan pengetahuan bidan tentang pertahanan terhadap infeksi nosokomial mayoritas kategori baik

5. Karakteristik responden berdasarkan pengetahuan bidan tentang tanda 
dan gejala infeksi nosokomial mayoritas kategori sedang

6. Karakteristik responden berdasarkan pengetahuan bidan tentang infeksi nosokomial mayoritas kategori sedang

7. Karakteristik responden berdasarkan tindakan pencegahan infeksi nosokomial mayoritas kategori baik

8. Hasil penelitian yang dilakukan dengan menggunakan uji Rank Spearman untuk melihat hubungan pengetahuan bidan $t$ tentang infeksi nosokomial dengan tindakan pencegahannya maka diperoleh hasil dengan nilai probabilitas $(p)=0,011$ $(\mathrm{p}<0,05)$ yang artinya ada hubungan dengan kekuatan hubungan $(r)=0,452$, berarti kekuatan hubungannya cukup dan hubungan ini bersifat positif yang artinya jika pengetahuan bidan tentang infeksi nosokomial cukup maka makin cukup nilai tindakan pencegahan infeksi yang diperoleh.

\section{Saran}

Saran dalam penelitian ini sebagai berikut:

1. Bagi bidan yang ada di rumah sakit, hasil penelitian ini hendaknya dapat diterima sebagai bahan masukan khususnya bagi bidan yang bekerja di ruang rawat pascabedah di Rumah Sakit Umum Imelda Pekerja Indonesia sehingga dalam pelaksanaan tindakan perawat mampu memahami dan mengambil tindakan yang tepat terhadap pencegahan infeksi nosokomial pada pasien-pasien pascabedah.

2. Bagi instansi pendidikan sebagai bahan masukan dalam proses pembelajaran yang terkait dengan infeksi nosokomial dan tindakan pencegahan infeksi nosokomial pada pasien pascabedah guna memperluas wawasan dalam pengembangan ilmu.

3. Bagi penelitian selanjutnya, hasil penelitian ini hendaknya dapat digunakan sebagai informasi ataupun data awal untuk pengembangan penelitian selanjutnya tentang infeksi nosokomial dan tindakan pencegahannya.

\section{DAFTRAR PUSTAKA}

Achmad, I. (2017). Manajemen perawatan pasien total care dan kejadian infeksi nosokomial di Ruang ICU RSUD Masohi tahun 2016. Global Health Science.

Aziz, A. H. (2017). Metodologi penelitian keperawatan dan kesehatan. In salemba medika.

Fitriana, Y., Pratiwi, K., \& Sutanto, A. V. (2015). Faktor-faktor yang berhubungan dengan perilaku orang tua dalam melakukan kekerasan verbal terhadap anak usia pra-sekolah. Jurnal Psikologi Undip.

https://doi.org/10.14710/jpu.14.1.8 1-93

Fitriany, M., Farouk, H., \& Taqwa, R. 
(2016). Perilaku masyarakat dalam pengelolaan kesehatan lingkungan (studi di Desa Segiguk sebagai salah satu Desa Penyangga Kawasan Hutan Suaka Margasatwa Gunung Raya Ogan Komering Ulu Selatan). Jurnal Penelitian Sains.

Ibrahim, H. (2019). Pengendalian infeksi nosokomial dengan kewaspadaan umum di rumah sakit. Retrieved from http://repositori.uinalauddin.ac.id/15016/1/Pengendali an infeksi nosokomial dengan kewaspadaan umum di rumah sakit .pdf

Kemenkumham. (2015). Peraturan Menteri Kesehatan Republik Indonesia Nomor 45 Tahun 2014 Tentang Penyelenggaraan Surveilans Kesehatan. Menteri Kesehatan Republik Indonesia Peraturan Menteri Kesehatan Republik Indonesia. https://doi.org/10.1093/bioinformat ics/btk045

Monica P, W. G. D. K. J. P. (2016). Faktor-faktor yang berhubungan dengan penerapan hand hygiene di Instalasi Rawat Inap Rumah Sakit Tingkat III R. W. Mongisidi Manado. Naskah Publikasi.

Notoatmodjo, S. (2012). Promosi kesehatan dan perilaku kesehatan. In Journal of Chemical Information and Modeling. https://doi.org/10.1017/CBO97811 07415324.004

Puspasari, Y. (2015). Hubungan pengetahuan, sikap dengan praktik perawat dalam pencegahan infeksi nosokomial di ruang rawat inap Rumah Sakit Islam Kendal. Jurnal Keperawatan Fikkes Vol 8(1).

Suharto, S., \& Suminar, R. (2017). Hubungan pengetahuan dan sikap perawat dengan tindakan pencegahan infeksi di ruang ICU rumah sakit. Jurnal Riset Hesti Medan Akper Kesdam I/BB Medan. https://doi.org/10.34008/jurhesti.v1 i1.1
Sulistyowati, D. (2016). Hubungan tingkat pengetahuan dan sikap perawat tentang infeksi nosokomial (inos) dengan perilaku pencegahan inos di ruang bedah RSUD DR. Moewardi Surakarta. (JKG) Jurnal Keperawatan Global. https://doi. org/10.37341/jkg.v1i1.14

Tombokan, C., Waworuntu, O., \& Buntuan, V. (2016). Potensi penyebaran infeksi nosokomial di ruangan instalasi rawat inap khusus tuberkulosis (irina c5) BLU Rsup Prof. Dr. R. D. Kandou Manado. Jurnal E-Biomedik. https://doi.org /10.35790/ebm.4.1.2016.11247

Zulkarnain. (2018). Analisis hubungan perilaku perawat terhadap tindakan pencegahan infeksi nosokomial (phelibitis) di Ruang Perawatan Interna RSUD Bima tahun 2018. JISIP, 2(1). 